\title{
Penyelenggaraan Tertib Administrasi Bidang Pertanahan Untuk Menunjang Pelaksanaan Kewenangan, Tugas dan Fungsi i Badan Pertanahan Nasional
}

\author{
Mira Novana Ardani \\ Fakultas Hukum Universitas Diponegoro \\ Jl. Prof. Soedarto,SH. Tembalang, Semarang \\ email : miranovana@yahoo.com
}

\begin{abstract}
On the basis of MPR Decree No.IV / MPR / 1978, a policy on land affairs, known as the chess discipline in the land sector, was published in Presidential Decree Number 7 of 1979, one of which included land administration discipline. How to conduct an orderly administration of land affairs to support the implementation of the authorities, duties and functions of the National Land Agency. This study uses normative juridical methods. Administration of Land Affairs in order to support the implementation of the authority, duties and functions of the National Land Agency by using a computerized system of land activities which is an electronic system.
\end{abstract}

Keywords: Administrative order, Land Affairs, National Land Agency

\begin{abstract}
Abstrak
Atas dasar Tap MPR No.IV/MPR/1978, dikeluarkan kebijaksanaan bidang pertanahan yang dikenal dengan catur tertib bidang pertanahan sebagaimana dimuat dalam Keppres Nomor 7 Tahun 1979, salah satunya meliputi tertib administrasi pertanahan. Bagaimana cara menyelenggarakan tertib administrasi bidang pertanahan untuk menunjang pelaksanaan kewenangan, tugas, dan fungsi Badan Pertanahan Nasional. Penelitian ini menggunakan metode yuridis normatif. Penyelenggaraan Tertib Administrasi Bidang Pertanahan untuk menunjang pelaksanaan kewenangan, tugas, dan fungsi Badan Pertanahan Nasional dengan cara menggunakan sistem komputerisasi kegiatan pertanahan yang merupakan sistem elektronik.
\end{abstract}

Kata kunci: Tertib administrasi, Pertanahan, Badan Pertanahan Nasional

\section{A. Pendahuluan}

Tanah memiliki peran yang sangat besar bagi keberlangsungan hidup umat manusia. Peran tersebut ditunjukkan mulai dari awal diciptakannya manusia hingga hari berpulangnya manusia itu sendiri pasti membutuhkan tanah. Tanah dapat dikelola, dimanfaatkan, digunakan sesuai dengan fungsinya. Di atas tanah dapat dibangun 
bangunan, dapat ditanami tanaman, ataupun dapat pula digunakan untuk melakukan usaha lainnya seperti melakukan usaha peternakan.

Pentingnya tanah bagi kehidupan mustinya harus digunakan sesuai dengan fungsi dan mafaat tanah yang bersangkutan. Terdapat kewajiban bagi pemegang hak atas tanah, baik perorangan, badan hukum, maupun sekelompok orang secara bersama-sama untuk selalu menjaga dan memelihara tanah yang dimilikinya. Kewajiban tersebut juga dicantumkan dalam ketentuan yang terdapat dalam Undang-Undang Nomor 5 Tahun 1960 tentang Undang-Undang Pokok Agraria.

Peran yang tak kalah penting dari tanah adalah dalam pembangunan. Tanah digunakan untuk mendukung berjalannya pembangunan, terutama dalam hal pembangunan dibidang infrastruktur. Untuk membangun tentu diperlukan tanah sebagai modal awalnya. Baik tanah pertanian maupun tanah non pertanian. Pembangunan yang sangat membutuhkan tanah, contohnya untuk pembangunan jalan tol, pelebaran jalan untuk kepentingan umum, dan lain sebagainya.

Mengingat pentingnya peran tanah, berdasarkan Tap MPR Nomor IV/MPR/1978 ditentukan agar pembangunan di bidang pertanahan diarahkan untuk menata kembali penggunaan, penguasaan, dan pemilikan tanah. Atas dasar Tap MPR Nomor IV/MPR/1978, Presiden mengeluarkan kebijaksanaan bidang pertanahan yang dikenal dengan catur tertib bidang pertanahan sebagaimana yang dimuat dalam Keppres Nomor 7 Tahun 1979, yang salah satunya meliputi tertib administrasi pertanahan, yang diarahkan pada program: ${ }^{1}$

a. Mempercepat proses pelayanan yang menyangkut urusan pertanahan;

b. Menyediakan peta dan data penggunaan tanah, keadaan sosial ekonomi masyarakat sebagai bahan dalam penyusunan perencanaan penggunaan tanah bagi kegiatankegiatan pembangunan;

c. Penyusunan data dan daftar pemilik tanah, tanah-tanah kelebihan batas maksimum, tanah-tanah absente dan tanah-tanah negara;

d. Menyempurnakan daftar-daftar kegiatan baik di Kantor Agraria maupun di kantor PPAT;

e. Mengusahakan pengukuran tanah dalam rangka pensertipikatan hak atas tanah.

${ }^{1}$ Samun Ismaya, Hukum Administrasi Pertanahan, Graha Ilmu, Yogyakarta, 2013, hal.22 
Pelaksanaan tertib administrasi pertanahan ini menjadi salah satu tugas dari Kementerian Agraria dan Tata Ruang, yakni menyelenggarakan perumusan dan pelaksanaan kebijakan pendaftaran hak tanah. Hal ini diatur dalam Peraturan Presiden Nomor 17 Tahun 2015 tentang Kementerian Agraria dan Tata Ruang, Pasal 15. Terdapat susunan organisasi dalam Kementerian Agraria dan Tata Ruang, yang salah satunya adanya direktorat jenderal hubungan hukum keagrariaan.

Direktorat jenderal hubungan hukum keagrariaan menurut Peraturan Presiden Nomor 17 Tahun 2015 tentang Kementerian Agraria dan Tata Ruang, Pasal 15 mempunyai tugas menyelenggarakan perumusan dan pelaksanaan kebijakan di bidang pengaturan, penetapan, dan pendaftaran hak tanah, pembinaan Pejabat Pembuat Akta Tanah, serta pemberdayaan masyarakat. Dalam pelaksanaan tugasnya, direktorat jenderal hubungan hukum keagrariaan menyelenggarakan fungsi sesuai yang terdapat dalam Pasal 16 yang terkait dengan pendaftaran tanah dan penyelenggaraan tertib administrasi pertanahan, seperti merumuskan, melaksanakan kebijakan di bidang pendaftaran hak tanah; penyusunan norma, standar, prosedur, dan kriteria di bidang pengaturan, penetapan, dan pendaftaran hak tanah; pemberian bimbingan teknis dan supervisi di bidang pengaturan, penetapan, dan pendaftaran hak tanah; pelaksanaan evaluasi dan pelaporan di bidang pengaturan, penetapan, dan pendaftaran hak tanah; serta pelaksanaan administrasi direktorat jenderal hubungan hukum keagrariaan.

Pelaksanaan tugas Kementerian Agraria dan Tata Ruang ada pada Badan Pertanahan Nasional (BPN). Dalam pelaksanaan tugasnya, BPN menggunakan unit organisasi dan sumber daya di lingkungan Kementerian Agraria dan Tata Ruang yang tugas dan fungsinya bersesuaian. Hal ini diterangkan dalam Peraturan Presiden Nomor 20 Tahun 2015 tentang Badan Pertanahan Nasional. Dalam Pasal 3 peraturan presiden tersebut, disebutkan fungsi BPN yang terkait dengan administrasi pertanahan seperti pelaksanaan koordinasi tugas, pembinaan, dan pemberian dukungan administrasi kepada seluruh unit organisasi di lingkungan BPN, serta pelaksanaan pengelolaan data informasi di bidang pertanahan.

Berdasarkan hal tersebut diatas, maka permasalahan yang dapat diteliti yakni bagaimana penyelenggaraan tertib administrasi bidang pertanahan untuk menunjang pelaksanaan kewenangan, tugas, dan fungsi Badan Pertanahan Nasional? 


\section{B. Metode penelitian}

Penelitian ini menggunakan pendekatan yuridis normatif. Dalam penelitian yuridis normatif, bahan pustaka digunakan sebagai bahan utama, yaitu bahan hukum primer yang terdiri dari norma dasar atau kaidah, ketentuan atau peraturan dasar, serta peraturan perundang-undangan. Selain itu dipergunakan juga bahan hukum sekunder sebagai data sekunder yang mencakup bahan hukum primer, sekunder, dan tertier. ${ }^{2}$

Teori hukum normatif adalah teori hukum yang memberi pemahaman norma yang dialami oleh ilmu hukum dogmatik dalam kegiatannya mendeskripsikan norma hukum, merumuskan norma hukum (membentuk peraturan perundang-undangan), dan menegakkan norma hukum (praktik yudisial). ${ }^{3}$ Metode penelitian hukum normatif merupakan meneliti hukum dari perspektif internal dengan objek penelitiannya adalah norma hukum. ${ }^{4}$

Untuk memahami permasalahan dalam penelitian, maka digunakan metode pengolahan data kualitatif. ${ }^{5}$ Maksud data kualitatif dalam penelitian ini adalah menggunakan data sekunder, yang diperoleh dari kepustakaan, antara lain:

a. Bahan hukum primer, yaitu bahan-bahan yang isinya mempunyai kekuatan mengikat kepada masyarakat, yaitu peraturan perundang-undangan. Bahan hukum primer dalam penulisan ini yakni Tap MPR Nomor IV/MPR/1978.

b. Bahan hukum sekunder, yaitu bahan-bahan hukum yang isinya menjelaskan mengenai bahan hukum primer. Buku bacaan yang ada kaitannya akan dijadikan acuan sebagai bahan hukum sekunder dalam penelitian ini.

c. Bahan hukum tertier, yaitu bahan-bahan penunjang yang memberikan penjelasan dari bahan primer dan bahan sekunder, contohnya dapat menggunakan kamus sebagai bahan hukum tertier.

\footnotetext{
${ }^{2}$ Soerdjono Soekanto dan Sri Mamudji, Penelitian Hukum Normatif Suatu Tinjauan Singkat, Jakarta, Raja Grafindo Persada, 1994, hlm.13

${ }^{3}$ I Made Pasek Diantha, Metodologi Penelitian Hukum Normatif Dalam Justifikasi Teori Hukum, Denpasar, Kencana, 2015, hlm.84

${ }^{4}$ Ibid, hlm.12

${ }^{5}$ Soerjono Soekanto, Pengantar Penelitian Hukum, cetakan 3, Jakarta, Universitas Indonesia (UI Press), 1986, hlm.132
} 


\section{Kerangka teori}

\section{a. Pengertian administrasi pemerintahan}

Pengertian administrasi pemerintahan berdasarkan Undang-Undang Nomor 30 Tahun 2014 tentang Administrasi Pemerintahan di dalam Pasal 1 angka1, administasi pemerintahan adalah tata laksana dalam pengambilan keputusan dan/ atau tindakan oleh badan/atau pejabat pemerintahan. Dalam ilmu hukum, hukum administrasi pemerintahan termasuk dalam hukum publik dan merupakan perpanjangan dari hukum tata negara. Lebih lanjut, diberikan definisi dari ahli mengenai pengertian hukum administrasi. $^{6}$

Menurut Oppen Heimer, hukum administrasi adalah sebagai suatu gabungan ketentuan-ketentuan yang mengikat badan-badan yang tinggi maupun rendah apabila badan itu menggunakan wewenangnya yang telah diberikan oleh hukum tata negara. Sedangkan menurut Logemann, hukum administrasi adalah seperangkat dari normanorma yang menguji hubungan hukum istimewa yang diadakan untuk memungkinkan para pejabat administrasi melakukan tugas mereka yang khusus. Bidang hukum administrasi pemerintahan sangat luas, banyak segi dan ragamnya. Dapat disimpulkan, hukum administrasi pemerintahan adalah hukum yang mengatur tentang kekuasaan pemerintah (eksekutif) dalam menjalankan wewenang di dalam kedudukan, tugas-tugas, dan fungsinya sebagai administrator negara termasuk pengambilan keputusan dan/atau tindakan. $^{7}$

\section{b. Kegiatan penyelenggaraan administrasi pertanahan}

Penyelenggaraan administrasi pertanahan di Indonesia meliputiu kegiatankegiatan: ${ }^{8}$

1). Pengaturan dan kegiatan penyediaan, peruntukan, penggunaan serta pemeliharaan bumi, air, dan ruang angkasa meliputi urusan pemerintahan di bidang pembagian tanah (redistribusi), perizinan peruntukan, penguasaan, pengendalian penguasaan dan pemilikan tanah beserta pengenaan sanksi, dan sebagainya.

\footnotetext{
${ }^{6}$ Yudhi Setiawan, Boedi Djatmiko Hadiatmodjo, Imam Ropii, Hukum Administrasi Pemerintahan Teori dan Praktik (Dilengkapi Dengan Beberapa Kasus Pertanahan), Jakarta, Rajawali Pers, 2017, hlm.1 ${ }^{7}$ Ibid, hlm.2-3

${ }^{8}$ Rusmadi Murad, Administrasi Pertanahan Pelaksanaan Hukum Pertanahan Dalam Praktek, Jakarta, Mandar Maju, 2013, hlm.16
} 
2). Menyelenggarakan urusan pemerintahan di bidang pertanahan di dalam hal: menjalankan, menentukan dan mengatur tentang hak-hak atas tanah yang dapat ditetapkan kepada orang-orang pemilik tanah, memberikan dan melindungi kepastian hukum dan hak atas tanah, hak dan kewajibannya serta penegakan hukum berikut sanksi-sanksinya.

3). Menyelenggarakan urusan pemerintahan di bidang pertanahan, yaitu: menjalankan dan mengatur hubungan-hubungan hukum yang dilakukan orang-orang yang obyek perjanjiannya berupa tanah, perizinan dan penetapannya, pengendalian dan pemberian wewenang pembuatan surat perjanjiannya serta pengelolaan administrasi ketatausahaannya.

4). Menyelenggarakan urusan pemerintahan di bidang pertanahan yaitu kegiatan pengukuran, pemetaan dalam rangka pemutakhiran data serta penentuan fisik tanah untuk dukungan penguatan di dalam pembukuan, pendaftaran, pemeliharaan dan pengeluaran alat pembuktian yang kuat.

5). Pembangunan administrasi pertanahan/Indonesia Land Administration Project (ILAP).

\section{c. Tugas dan fungsi Kementerian Agraria dan Tata Ruang}

Kementerian Agraria dan Tata Ruang berada di bawah dan bertanggung jawab kepada Presiden, dan dipimpin oleh Menteri. Sesuai dengan isi Pasal 2, Peraturan Presiden Nomor 17 Tahun 2015 tentang Kementerian Agraria dan Tata Ruang, Kementerian Agraria dan Tata Ruang mempunyai tugas menyelenggarakan urusan pemerintahan di bidang agraria/pertanahan dan tata ruang untuk membantu presiden dalam menyelenggarakan pemerintahan negara.

Fungsi Kementerian Agraria dan Tata Ruang, sesuai dengan Pasal 3 Peraturan Presiden Nomor 17 Tahun 2015 tersebut, antara lain:

1). Perumusan, penetapan, dan pelaksanaan kebijakan di bidang tata ruang, infrastruktur keagrariaan/pertanahan, hubungan hukum keagrariaan/pertanahan, penataan agraria/pertanahan, pengadaan tanah, pengendalian pemanfaatan ruang dan penguasaan tanah, serta penanganan masalah agraria/pertanahan, pemanfaatan ruang, dan tanah; 
2). Koordinasi pelaksanaan tugas, pembinaan dan pemberian dukungan administrasi kepada seluruh unsur organisasi di lingkungan Kementerian Agraria dan Tata Ruang;

3). Pengelolaan barang milik/kekayaan negara yang menjadi tanggung jawab Kementerian Agraria dan Tata Ruang;

4). Pengawasan atas pelaksanaan tugas di lingkungan Kementerian Agraria dan Tata Ruang;

5). Pelaksanaan bimbingan teknis dan supervisi atas pelaksanaan urusan Kementerian Agraria dan Tata Ruang di daerah; dan

6). Pelaksanaan dukungan yang bersifat substantif kepada seluruh unsur organisasi di lingkungan Kementerian Agraria dan Tata Ruang.

d. Tugas dan fungsi Badan Pertanahan Nasional

Badan Pertanahan Nasional (BPN) adalah lembaga pemerintah non kementerian yang berada di bawah dan bertanggung jawab kepada presiden. BPN dipimpin oleh seorang kepala. BPN mempunyai tugas, seperti yang tercantum dalam Pasal 2 Peraturan Presiden Nomor 20 Tahun 2015 tentang Badan Pertanahan Nasional yaitu melaksanakan tugas pemerintahan di bidang pertanahan sesuai dengan ketentuan peraturan perundang-undangan.

Pasal 3 Peraturan Presiden Nomor 20 Tahun 2015 tentang Badan Pertanahan Nasional berisi mengenai fungsi BPN, antara lain:

1). Penyusunan dan penetapan kebijakan di bidang pertanahan;

2). Perumusan dan pelaksanaan kebijakan di bidang survei, pengukuran, dan pemetaan;

3). Perumusan dan pelaksanaan kebijakan di bidang penetapan hak tanah, pendaftaran tanah, dan pemberdayaan masyarakat;

4). Perumusan dan pelaksanaan kebijakan di bidang pengaturan, penataan dan pengendalian kebijakan pertanahan;

5). Perumusan dan pelaksanaan kebijakan di bidang pengadaan tanah;

6). Perumusan dan pelaksanaan kebijakan di bidang pengendalian dan penanganan sengketa dan perkara pertanahan;

7). Pengawasan atas pelaksanaan tugas di lingkungan BPN; 
8). Pelaksanaan koordinasi tugas, pembinaan, dan pemberian dukungan administrasi kepada seluruh unit organisasi di lingkungan BPN;

9). Pelaksanaan pengelolaan data informasi lahan pertanian pangan berkelanjutan dan informasi di bidang pertanahan;

10). Pelaksanaan penelitian dan pengembangan di bidang pertanahan; dan

11). Pelaksanaan pengembangan sumber daya manusia di bidang pertanahan.

Dalam melaksanakan tugas dan fungsinya, BPN dikoordinasikan oleh menteri yang menyelenggarakan urusan pemerintahan di bidang agraria dan tata ruang.

\section{Pembahasan}

Penyelenggaraan tertib administrasi memang sangatlah diperlukan dalam bidang pertanahan. Hal ini dapat dilihat dari penyelenggaraan kegiatan pendaftaran tanah, yang mana pendaftaran tanah merupakan rangkaian kegiatan yang dilakukan oleh pemerintah secara terus-menerus, berkesinambungan dan teratur, meliputi pengumpulan, pengolahan, pembukuan, dan penyajian serta pemeliharaan data fisik dan data yuridis, dalam bentuk peta daftar, mengenai bidang-bidang tanah dan satuan-satuan rumah susun, termasuk pemberian surat tanda bukti haknya bagi bidang-bidang tanah yang sudah ada haknya dan hak milik atas satuan rumah susun serta hak-hak tertentu yang membebaninya. Pengertian pendaftaran tanah ini dapat dilihat dalam Pasal 1 angka 1 Peraturan Pemerintah Nomor 24 Tahun 1997 tentang Pendaftaran Tanah.

Tertib administrasi pertanahan dalam kegiatan pendaftaran tanah, dapat dilihat dari tujuan pendaftaran tanah itu sendiri, yakni dalam Pasal 3 Peraturan Pemerintah Nomor 24 Tahun 1997 tentang Pendaftaran Tanah yakni:

1). Untuk memberikan kepastian hukum dan perlindungan hukum kepada pemegang hak atas suatu bidang tanah, satuan rumah susun dan hak-hak lain yang terdaftar agar dengan mudah dapat membuktikan dirinya sebagai pemegang hak yang bersangkutan;

2).Untuk menyediakan informasi kepada pihak-pihak yang berkepentingan termasuk Pemerintah agar dengan mudah dapat memperoleh data yang diperlukan dalam mengada-kan perbuatan hukum mengenai bidang-bidang tanah dan satuan-satuan rumah susun yang sudah terdaftar;

3). Untuk terselenggaranya tertib administrasi pertanahan. 
Pemberian jaminan kepastian hukum di bidang pertanahan itu sendiri memerlukan: ${ }^{9}$

1). Tersedianya perangkat hukum tertulis, yang lengkap dan jelas serta dilaksanakan secara konsisten;

2). Penyelenggaraan pendaftaran tanah yang efektif.

Dengan tersedianya perangkat hukum yang tertulis, siapa pun yang berkepentingan akan dengan mudah mengetahui kemungkinan apa yang tersedia baginya untuk menguasai dan menggunakan tanah yang diperlukannya, bagaimana cara memperolehnya, hak-hak, kewajiban serta larangan-larangan apa yang ada dalam menguasai tanah dengan hak-hak tertentu, sanksi apa yang dihadapinya jika diabaikan ketentuan-ketentuan yang bersangkutan, serta hal-hal lain yang berhubungan dengan penguasaan dan penggunaan tanah yang dipunyainya.

Untuk menunjang penyelenggaraan tertib administrasi pertanahan yang pelaksanaannya merupakan tugas, wewenang dan fungsi dari BPN, terdapat aturan untuk membantu mengefisienkan, menertibkan khususnya terkait kegiatan administrasi pertanahan, telah diterbitkan aturan-aturan yang berlaku, seperti yang terdapat dalam Peraturan Menteri Agraria dan Tata Ruang/Kepala Badan Pertanahan Nasional Nomor 6 Tahun 2018 tentang Pendaftaran Tanah Sistematis Lengkap (PTSL), yakni dalam peraturan tersebut dijelaskan mengenai pendokumentasian dan penyerahan hasil kegiatan, Pasal 36, bahwa panitia ajudikasi PTSL melakukan pengumpulan, pengelompokan, pengolahan, dan penyimpanan data PTSL, yang meliputi:

a. Dokumen data yuridis yang terdiri dari identitas pemegang hak, alas hak, berita acara yang dibuat panitia, bukti pengumuman, Berita Acara Pengesahan data fisik dan data yuridis dan surat keputusan pemberian hak;

b. Dokumen data fisik: data pengukuran dan perhitungan hasil pengukuran, gambar ukur, peta bidang tanah, dan surat ukur;

c. Daftar isian pendaftaran tanah dan hak atas tanah;

d. Buku tanah;

e. Sertipikat hak atas tanah;

f. Bukti-bukti administrasi keuangan; dan

g. Data administrasi lainnya.

${ }^{9}$ Boedi Harsono, Hukum Agraria Indonesia, Sejarah Pembentukan Undang-Undang Pokok Agraria Isi Dan Pelaksanaannya, Djambatan, Jakarta, 2008, hlm.69 
Penyimpanan data tersebut, dapat dilakukan dalam bentuk elektronik.

Dalam penyerahan hasil PTSL, sesuai Pasal 37, ketua panitia ajudikasi PTSL menyerahkan hasil pelaksanaan PTSL kepada Kepala Kantor Pertanahan pada akhir kegiatan PTSL dan disertai data PTSL. Penyerahan hasil pelaksanaan kegiatan PTSL dibuat dalam bentuk Berita Acara Serah Terima berkas dan warkah hasil kegiatan PTSL yang ditandatangani oleh Ketua Panitia Ajudikasi PTSL dan Kepala Kantor Pertanahan. Hasil kegiatan PTSL tersebut kemudian disimpan, didokumentasikan dan diarsipkan oleh Kepala Kantor Pertanahan.

Penyimpanan, pendokumentasian, serta pengarsipan berkas-berkas hasil kegiatan PTSL tersebut tentu tidaklah mudah. Hal ini dikarenakan dalam satu kali penetapan lokasi saja, meliputi satu wilayah desa/kelurahan atau secara bertahap dalam satu hamparan. Terlebih, jika dilihat dari Pasal 4 nya, PTSL meliputi seluruh objek pendaftaran tanah di seluruh wilayah Republik Indonesia. Objek PTSL meliputi seluruh bidang tanah tanpa terkecuali, baik bidang tanah yang belum ada hak atas tanahnya maupun bidang tanah hak yang memiliki hak dalam rangka memperbaiki kualitas data pendaftaran tanah. Berapa banyak berkas, kertas yang harus disimpan oleh Kantor Pertanahan jika nantinya seluruh bidang tanah di wilayah Republik Indonesia sudah terdaftar dan terpetakan. Resiko untuk berkas hilang, rusak tidak dapat dipungkiri. Padahal, apabila kita melihat dalam ketentuan pasal pasal 192 Peraturan Menteri Negara Agraria/Kepala Badan Pertanahan Nasional Nomor 3 Tahun 1997 tentang Ketentuan Pelaksanaan Peraturan Pemerintah Nomor 24 Tahun 1997 tentang Pendaftaran Tanah, mengenai penyajian informasi data fisik dan data yuridis, yakni dalam ayat (1) nya diterangkan bahwa semua daftar umum dan dokumen-dokumen yang telah dipergunakan sebagai dasar pendaftaran merupakan dokumen negara yang harus disimpan dan dipelihara menurut peraturan perundang-undangan yang berlaku.

Masalah tanah merupakan sesuatu yang sangat kompleks sebab menyangkut banyak aspek kehidupan masyarakat. Melihat banyaknya masalah pertanahan yang terjadi, Badan Pertanahan Nasional (BPN) selaku badan pemerintahan yang bertugas untuk menangani masalah pertanahan mulai melakukan antisipasi terhadap masalah yang timbul. Hal ini ditindaklanjuti dengan dibentuknya Pusat Data dan Informasi Pertanahan (Pusdatin), sesuai dengan Peraturan Presiden Nomor 10 Tahun 2006. Adapun tugas dari Pusdatin adalah melaksanakan 
pengumpulan, pengolahan, penyajian data dan informasi pertanahan serta membangun dan mengembangkan Sistem Informasi Pertanahan dan Manajemen Pertanahan Nasional (SIMTANAS). Maka dibuatlah sistem KKP (Komputerisasi Kantor Pertanahan), yaitu sistem pelayanan pertanahan yang telah terkomputerisasi, sehingga data tentang bidang tanah baik tekstual maupun spasialnya dapat terintegrasi dengan baik. KKP dilaksanakan dengan tujuan untuk pemeliharaan data tekstual maupun spasial dan monitoring pelayanan pertanahan. ${ }^{10}$

BPN RI telah melakukan beberapa kegiatan terkait dengan Implementasi Teknologi Informasi dan Komunikasi (TIK), seperti implementasi Komputerisasi Kantor Pertanahan atau Land Office Computerisation (LOC) yang dimulai pada tahun 1997 dan sampai saat ini sudah mengalami perubahan yang ke 3 (LOC 2B), implementasi Larasita yaitu layanan mobile (layanan jemput masyarakat) yang merupakan pengembangan dari KKP pada tahun 2006 dan sampai saat ini masih berlangsung pengembangannya. Serta pembuatan Grand Desain TIK BPN RI yang dilakukan pada tahun 2007. Penyusunan Grand Desain TIK ini merupakan salah satu upaya terencana mengembangkan teknologi informasi dan komunikasi dalam mendukung suksesnya pelaksanaan rencana strategis BPN RI. ${ }^{11}$

Grand Desain TIK diantaranya memaparkan tentang Sistem Informasi Manajemen Pertanahan Nasional (SIMTANAS), yaitu sistem informasi yang terdiri dari aplikasiaplikasi yang terkait dengan kegiatan utama BPN di bidang pertanahan dan Sistem Informasi Pengelolaan Administrasi Ketatausahaan Terpadu (SIMPADU), yaitu sistem informasi yang terdiri dari aplikasi-aplikasi yang terkait dengan kegiatan administrasi di BPN RI. Grand Desain TIK merupakan dokumentasi perencanaan pada tingkat strategis yang memerlukan tindak lanjut yang lebih rinci. Dalam grand desain disebutkan beberapa agenda besar terkait dengan implementasi TIK antara lain: pembuatan standardisasi SIMTANAS dan SIMPADU, pengembangan sistem informasi untuk mendukung kegiatan pelayanan pertanahan dan kegiatan-kegiatan lainnya.

\footnotetext{
${ }^{10}$ Patriot Ginanjar S,Bambang Sudarsono,Bandi Sasmito, Kajian Efektivitas Pemanfaatan Sistem Geokkp Untuk Penerbitan Sertipikat Tanah Di Kantor Pertanahan Kabupaten Kendal Provinsi Jawa Tengah, Jurnal Geodesi Undip, April 2014, Volume 3, Nomor 2, Tahun 2014 (ISSN: 2337-845X) ${ }^{11}$ Suci Ratnawatia, Dana Indra Sensuseb, Riri Satria, Strategi Manajemen Perubahan Implementasi TIK Pada Badan Pertanahan Nasional RI (Studi Kasus Komputerisasi Kantor Pertanahan), Studia Informatika: Jurnal Sistem Informasi, Volume 5, Nomor 2, Tahun 2012, hlm. 1-10, p-ISSN 1979-0767
} 
Pengertian komputerisasi kegiatan pertanahan sesuai Pasal 1 angka 15 Peraturan Menteri Agraria dan Tata Ruang/Kepala Badan Pertanahan Nasional Nomor 6 Tahun 2018 tentang Pendaftaran Tanah Sistematis Lengkap adalah aplikasi utama dalam menunjang pelaksanaan kewenangan, tugas dan fungsi Kementerian Agraria dan Tata Ruang/Badan Pertanahan Nasional berbasis teknologi informasi dan komunikasi yang dibangun dan dikembangkan mengacu kepada alur, persyaratan, waktu, biaya, dan kewenangan sesuai dengan ketentuan peraturan perundang-undangan.

Untuk melengkapi adanya komputerisasi dalam kegiatan pertanahan tersebut, sebetulnya sudah ada aturan yakni Peraturan Menteri Negara Agraria/Kepala Badan Pertanahan Nasional Nomor 3 Tahun 1997 tentang Ketentuan Pelaksanaan Peraturan Pemerintah Nomor 24 Tahun 1997 tentang Pendaftaran Tanah yang mengatur mengenai digitalisasi dalam kegiatan pendaftaran tanah. Seperti yang terdapat dalam pasal 184 , yang mengulas penyimpanan data dan dokumen dapat disimpan dalam bentuk digital, imaging system atau mikro film, pasal 186, media penyimpan data dan dokumen yang berbentuk digital, imaging system atau mikro film, harus disimpan di Kantor Pertanahan dalam tempat khusus sesuai dengan tata cara yang standard untuk penyimpanan media yang bersangkutan. Termasuk juga dalam hal pembuatan peta pendaftaran, yang tercantum dalam Pasal 142 nya, peta pendaftaran yang dibuat dengan memetakan hasil pengukuran bidang tanah pada peta dasar pendaftaran dapat dibuat juga dalam bentuk digital.

Pengertian digital sendiri belum dijelaskan dalam Peraturan Menteri Negara Agraria/Kepala Badan Pertanahan Nasional Nomor 3 Tahun 1997 tentang Ketentuan Pelaksanaan Peraturan Pemerintah Nomor 24 Tahun 1997 tentang Pendaftaran Tanah. Apabila melihat dari wikipedia, digital berasal dari kata digitus, dalam bahasa yunani berarti jari-jemari. Digital merupakan penggambaran dari suatu keadaan bilangan yang terdiri dari angka 0 dan 1 atau off dan on (bilangan biner). Semua sistem komputer menggunakan sistem digital sebagai basis datanya. ${ }^{12}$

Mengenai pemeliharaan peta pendaftaran, sesuai pasal 144 Peraturan Menteri Negara Agraria/Kepala Badan Pertanahan Nasional Nomor 3 Tahun 1997 tentang Ketentuan Pelaksanaan Peraturan Pemerintah Nomor 24 Tahun 1997 tentang Pendaftaran Tanah ayat (3), untuk peta pendaftaran yang dibuat dalam bentuk digital,

${ }^{12}$ https://id.wikipedia.org/wiki/Digital, diakses 22 Oktober 2019 
dibuat data duplikatnya (back-up), dan setiap data dilaksanakan pembaharuan data digitalnya, serta dalam ayat (4) nya untuk peta pendaftaran yang disimpan dalam bentuk digital, sedapat mungkin disimpan juga peta pendaftaran dalam bentuk drafting-film. Nampak bahwa dalam hal pemeliharaan peta pendaftaran pun telah diupayakan penyimpanan datanya dalam bentuk digital.

Demikian halnya dengan pembuatan surat ukur yang terdapat dalam pasal 157 ayat (4) nya, apabila data fisik suatu bidang tanah disimpan dalam bentuk digital maka pembuatan surat ukur dilakukan dengan mencetak data fisik dimaksud pada lembar surat ukur. Sesuai dengan isi Pasal 178 nya, Untuk kepentingan pemegang hak atau pengelola tanah wakaf, diterbitkan sertipikat hak atas tanah, hak pengelolaan, tanah wakaf, hak milik atas satuan rumah susun, dan hak tanggungan. Sertipikat jika kita melihat dalam ketentuan yang terdapat dalam Peraturan Menteri Agraria dan Tata Ruang/kepala Badan Pertanahan Nasional Nomor 7 Tahun 2016 tentang Bentuk dan Isi Sertipikat Hak Atas Tanah dengan pertimbangan untuk melaksanakan pendaftaran tanah berdasarkan asas sederhana, aman, terjangkau, mutakhir dan terbuka, dalam aturan ini disebutkan secara bertahap data pendaftaran tanah disimpan dan disajikan secara elektronik, sehingga perlu disesuaikan mengenai bentuk dan isi sertipikat hak atas tanah dengan perkembangan hukum, teknologi dan kebutuhan masyarakat, maka pendaftaran tanah dilakukan dengan menggunakan sistem komputerisasi kegiatan pertanahan.

Sistem komputerisasi kegiatan pertanahan yang dimaksud dalam Pasal 2 Peraturan Menteri Agraria dan Tata Ruang/kepala Badan Pertanahan Nasional Nomor 7 Tahun 2016 tentang Bentuk dan Isi Sertipikat Hak Atas Tanah menggunakan sistem elektronik berbentuk aplikasi tersistem, terintegrasi dan dapat digunakan dengan atau tanpa jaringan, serta dapat langsung tersinkronisasi secara otomatis. Dalam hal penerbitan sertipikat, baik itu sertipikat hak atas tanah, hak milik atas satuan rumah susun, hak tanggungan dan sertipikat tanah wakaf menurut Pasal 4 nya, dicetak pada satu lembar berdasarkan informasi yang diperoleh dari data fisk dan data yuridis. Hal ini mustinya memang merupakan terobosan yang dilakukan oleh pemerintah khususnya terkait bentuk sertipikat yang diterbitkan oleh kantor pertanahan yakni menjadi cukup satu lembar. Tentu saja data yang terkait mengenai kutipan peta pendaftarannya bisa tetap ditemukan dalam data yang telah tersimpan melalui sistem digital dengan menggunakan 
komputerisasi. Namun, Peraturan Menteri Agraria dan Tata Ruang/kepala Badan Pertanahan Nasional Nomor 7 Tahun 2016 telah dicabut dan dinyatakan tidak berlaku dengan keluarnya Peraturan Menteri Agraria dan Tata Ruang/Kepala Badan Pertanahan Nasional Nomor 7 Tahun 2019 tentang Perubahan Kedua Atas Peraturan Menteri Negara Agraria/ Kepala Badan Pertanahan Nasional Nomor 3 Tahun 1997 Tentang Ketentuan Pelaksanaan Peraturan Pemerintah Nomor 24 Tahun 1997 Tentang Pendaftaran Tanah.

Pada ketentuan Peraturan Menteri Agraria dan Tata Ruang/Kepala Badan Pertanahan Nasional Nomor 7 Tahun 2019 tentang Perubahan Kedua Atas Peraturan Menteri Negara Agraria/ Kepala Badan Pertanahan Nasional Nomor 3 Tahun 1997 Tentang Ketentuan Pelaksanaan Peraturan Pemerintah Nomor 24 Tahun 1997 Tentang Pendaftaran Tanah, dalam Pasal 102, dalam penyampaian akta yang telah dibuat oleh Pejabat Pembuat Akta Tanah (PPAT) kepada Kepala Kantor Pertanahan, juga telah terdapat upaya untuk mendukung adanya sistem digital yang diterapkan. Hal ini terlihat bahwa penyampaian akta tersebut dapat berupa dokumen elektronik, yang dilakukan melalui sistem elektronik. Pengertian sistem elektronik menurut Pasal 1 angka 12 b Peraturan Menteri Agraria dan Tata Ruang/Kepala Badan Pertanahan Nasional Nomor 7 Tahun 2019 tersebut adalah serangkaian perangkat dan prosedur elektronik yang berfungsi mempersiapkan, mengumpulkan, mengolah, menganalisa, menyimpan, menampilkan, mengumumkan, mengirimkan, dan/atau menyebarkan informasi elektronik. Selain itu, dalam Pasal 1 angka 12 d diatur mengenai pengertian dokumen elektronik, yaitu setiap informasi elektronik yang dibuat, diteruskan, dikirimkan, diterima, atau disimpan dalam bentuk analog, digital, elektromagnetik, optikal, atau sejenisnya, yang dapat dilihat, ditampilkan, dan/atau didengar melalui komputer atau sistem elektronik, termasuk tetapi tidak terbatas pada tulisan, suara, gambar, peta, rancangan, foto atau sejenisnya, huruf, tanda, angka, kode akses, simbol atau perforasi yang memiliki makna atau arti atau dapat dipahami oleh orang yang mampu memahaminya. Untuk dapat mengakses sistem elektronik, PPAT wajib menjadi pengguna terdaftar dalam sistem elektronik. Selain untuk penyampaian akta PPAT dalam bentuk dokumen elektronik dan pembuatan surat pengantar akta, sistem elektronik dapat digunakan juga untuk pelaksanaan jabatan PPAT lainnya, dan atau pembinaan dan pengawasan atas pelaksanaan jabatan PPAT. Dalam penerapan sistem 
elektronik tersebut diselenggarakan secara bertahap menyesuaikan dengan kesiapan data pendukung.

Sistem elektronik diterapkan pula dalam hal penyimpanan buku tanah dengan bentuk basis data dalam sistem elektronik, dan dapat dicetak dengan menggunakan daftar isian buku tanah. Hal ini dituangkan dalam Pasal 163 A. Pasal 178 A, untuk sertipikat, selain dapat dicetak dengan menggunakan daftar isian sertipikat, dapat juga dibuat dalam bentuk dokumen elektronik melalui sistem elektronik. Sertipikat dalam bentuk dokumen elektronik merupakan ekstraksi dari basis data buku tanah dalam sistem elektronik, yang disahkan dengan tanda tangan elektronik sesuai ketentuan peraturan perundang-undangan. Sertipikat dalam bentuk dokumen elektronik tersebut dapat dicetak sebagai salinan dokumen elektronik untuk diserahkan kepada pemegang hak.

Mengenai penyelenggaraan tata usaha pendaftaran tanah dapat pula dilaksanakan melalui sistem elektronik. Hal ini diatur dalam Pasal 192 A. Data hasil penyelenggaraan tersebut disimpan secara elektronik dengan bentuk basis data dalam sistem elektronik. Untuk pecetakan dokumen, dapat dicetak dengan menggunakan daftar isian atau dibuat dalam bentuk dokumen elektronik. Dokumen elektronik hasil penyelenggaraan tata usaha pendaftaran tanah dalam bentuk dokumen elektronik merupakan ekstraksi dari basis data dalam sistem elektronik. Dokumen tersebut disahkan dengan tanda tangan elektronik sesuai dengan ketentuan peraturan perundang-undangan dan dapat dicetak sebagai salinan dokumen elektronik. Pengertian tanda tangan elektronik menurut Pasal 1 angka 12 c adalah tanda tangan yang terdiri atas Informasi Elektronik yang dilekatkan, terasosiasi atau terkait dengan Informasi Elektronik lainnya yang digunakan sebagai alat verifikasi dan autentikasi. Dokumen elektronik hasil penyelenggaraan tata usaha pendaftaran tanah mempunyai kekuatan hukum yang sama dengan penyelenggaraan tata usaha pendaftaran tanah yang dicetak dengan menggunakan daftar-daftar isian.

Mulai dari penyimpanan data, terlebih terkait mengenai data pendaftaran tanah, maupun pendaftaran tanah sistematis lengkap sampai dengan penerbitan sertipikat telah diatur mengenai sistem komputerisasi yang dapat digunakan. Hal ini tentu saja sangat perlu didukung dengan kesiapan baik dari basis datanya, perangkat yang mendukung, serta sumber daya manusianya. Setelah sistem komputerisasi tersebut telah berjalan 
dengan baik, harapannya data-data pertanahan terintegrasi dengan baik, sehingga dapat menunjang pelaksanaan kewenangan, tugas, dan fungsi Badan Pertanahan Nasional khususnya terkait administrasi pertanahan, seperti pekerjaan yang lebih efektif.

\section{Simpulan}

Berdasarkan penulisan diatas, maka dapat diambil kesimpulan sebagai berikut: Terdapat aturan-aturan yang mengakomodir penyelenggaraan tertib administrasi bidang pertanahan guna menunjang pelaksanaan kewenangan, tugas, dan fungsi Badan Pertanahan Nasional yakni dengan menciptakan aplikasi yang berbasis teknologi informasi dan komunikasi dengan cara melakukan sistem komputerisasi, diantaranya mengenai:

a. Penyimpanan data PTSL dapat dilakukan dalam bentuk elektronik;

b. Penyimpanan data dan dokumen pendaftaran tanah dapat disimpan dalam bentuk digital, imaging system atau mikro film;

c. Pemeliharaan peta pendaftaran pun telah diupayakan penyimpanan datanya dalam bentuk digital;

d. Penyampaian akta yang telah dibuat oleh Pejabat Pembuat Akta Tanah (PPAT) kepada Kepala Kantor Pertanahan dilakukan melalui sistem elektronik;

e. Sistem elektronik dapat digunakan juga untuk pelaksanaan jabatan PPAT lainnya, dan atau pembinaan dan pengawasan atas pelaksanaan jabatan PPAT.

f. Penyimpanan buku tanah dengan bentuk basis data dalam sistem elektronik, dan dapat dicetak dengan menggunakan daftar isian buku tanah.

g. Sertipikat, selain dapat dicetak dengan menggunakan daftar isian sertipikat, dapat juga dibuat dalam bentuk dokumen elektronik melalui sistem elektronik.

h. Penyelenggaraan tata usaha pendaftaran tanah dapat pula dilaksanakan melalui sistem elektronik.

\section{E. DAFTAR PUSTAKA}

Harsono, Boedi, Hukum Agraria Indonesia, Sejarah Pembentukan Undang-Undang Pokok Agraria Isi Dan Pelaksanaannya, Djambatan, Jakarta, 2008

https://id.wikipedia.org/wiki/Digital, diakses 22 Oktober 2019

Made, I, Pasek Diantha, Metodologi Penelitian Hukum Normatif Dalam Justifikasi Teori Hukum, Denpasar, Kencana, 2015

Murad, Rusmadi, Administrasi Pertanahan Pelaksanaan Hukum Pertanahan Dalam Praktek, Jakarta, Mandar Maju, 2013 
Patriot Ginanjar S,Bambang Sudarsono,Bandi Sasmito, Kajian Efektivitas Pemanfaatan Sistem Geokkp Untuk Penerbitan Sertipikat Tanah Di Kantor Pertanahan Kabupaten Kendal Provinsi Jawa Tengah, Jurnal Geodesi Undip, April 2014, Volume 3, Nomor 2, Tahun 2014

Samun Ismaya, Hukum Administrasi Pertanahan, Graha Ilmu, Yogyakarta, 2013

Setiawan, Yudhi, Boedi Djatmiko Hadiatmodjo, Imam Ropii, Hukum Administrasi Pemerintahan Teori dan Praktik (Dilengkapi Dengan Beberapa Kasus Pertanahan), Jakarta, Rajawali Pers, 2017

Soekanto, Soerdjono, dan Sri Mamudji, Penelitian Hukum Normatif Suatu Tinjauan Singkat, Jakarta, Raja Grafindo Persada, 1994

Soekanto, Soerjono, Pengantar Penelitian Hukum, cetakan 3, Jakarta, Universitas Indonesia (UI Press), 1986

Suci Ratnawatia, Dana Indra Sensuseb, Riri Satria, Strategi Manajemen Perubahan Implementasi TIK Pada Badan Pertanahan Nasional RI (Studi Kasus Komputerisasi Kantor Pertanahan), Studia Informatika: Jurnal Sistem Informasi, Volume 5, Nomor 2, Tahun 2012, hlm. 1-10, p-ISSN 1979-0767 